\title{
Analysis of Financial Literacy in a College Population
}

\author{
Christopher Jacobsen \\ University of Massachusetts Dartmouth \\ Joao Correia \\ University of Massachusetts Dartmouth
}

The financial literacy of today's students is essential to their future success. Colleges and universities struggle to develop methods for training students in financial literacy. This study investigates the financial literacy of college students, looking at individual factors of financial background, race, gender, major and motivation in order to understand if students are learning enough to be considered financially literate, and how to structure a course in order to improve overall literacy. Findings demonstrate a lack of financial literacy among students who aren't business majors, haven't been exposed to previous financial courses, and lack overall confidence in their financial literacy.

Keywords: Financial Literacy, College Population, College Student Motivation, College Student Confidence, Financial Courses, Financial background, Financial Knowledge

\section{INTRODUCTION}

The term financial literacy is a concept that has been regularly associated with the baby boomer generation and their overall knowledge of financial activities. Years ago, financial literacy was simply preparation for retirement, but in today's world the benefits of financial literacy at an early age could set a solid foundation for an individual's future. Financial literacy has been shown to positively impact savings, retirement and overall wealth while reducing financial debt, and anxiety (Lusardi \& Mitchell, 2007; Hilgert, Hogarth, \& Beverly, 2003). In 2009, increasing consumer financial literacy became a US public policy objective in order to improve welfare through better decision making (Dodaro, 2011). Despite the importance of financial literacy, many institutions do not offer opportunities for college students to increase their financial knowledge.

A recent study shows that the average passing rate of a nationwide financial literacy survey in the United States is around $60 \%$, demonstrating the increasing need of educating students on financial matters (NEFC, 2017). Current research in financial literacy focuses on social inequalities that effect financial literacy. These include race, income level, gender, education, participation, and family connections (Lusardi \& Wallace, 2013; Kramer, 2016; Firli, 2017). While there are clear benefits to financial literacy, more needs to be done to establish exactly how we should be teaching financial literacy, as well as what role confidence and motivation can play. 
A college or university plays a pivotal role in providing the resources for students to develop financial knowledge, regardless of demographics, field of study, and cognitive ability.

This study looks to explore preferred methods for teaching financial literacy. Namely, the primary focus is to establish the ability and motivations of students to take a financial course in order to improve their financial literacy. This will contribute to existing financial literacy theory by offering strategies for training, as well as possible moderators for the individual difference variables previous researchers have found. In practice, the results will help colleges and universities implement better financial literacy programs for all students. This study is broken into several sections. First, a review of the literature is explored, followed by the hypotheses justification. Next, the methodology and procedures are explained. The results are presented and discussed, followed by implications, limitations and ideas for future research.

\section{LITERATURE REVIEW}

The topic of financial literacy began receiving attention in the 1960's (Cagan, 1965; Katona, 1965). This research involved financial preparation including a focus on the benefits of savings. Emphasis was placed on tools and strategies used for saving and investing in order to retire early. Most of this early work heavily focused on retirement planning and pension plans (Cagan, 1965; Katona, 1965). Little attention was paid to using education to create financial literacy. Eventually, financial literacy researchers began to focus on how to accurately measure financial literacy in order to understand its important role in financial planning (Marcolin \& Abraham, 2006; Danes \& Hira 1987; Chen \& Volpe, 1998; Lusardi \& Mitchell, 2007; Gustman \& Steinmeier, 2001). Surprisingly, researchers began to discover an overall lack of financial literacy in the US population with participants scoring anywhere from $20-60 \% / 100 \%$ on financial literacy tests (Employee Benefit Research Institute, 1995; KPMG, 1995; PSRA, 1996, 1997; Oppenheimer Funds/Girls Inc., 1997; Vanguard Group/Money Magazine, 1997; Lusardi \& Mitchell, 2008). Many of these studies find that people fail to make correct financial decisions due to an overall lack of financial education. This trend is also seen with college students, as their overall lack of financial literacy training, and therefore understanding was demonstrated by average financial literacy test scores of roughly 50\% (Danes \& Hira, 1987; Volpe, Chen, \& Pavlicko, 1996; Chen \& Volpe, 1998).

Bernheim, Garrett, and Maki's (2001) seminal work on financial literacy education found that middle age individuals who took a personal financial management course in high school tended to save a higher proportion of their incomes than others who did not. As financial literacy education has grown in importance, researchers have explored individual differences that may impact financial literacy. Research has found that women and minorities are less financially literate (Lusardi \& Mitchell, 2008; Chen \& Volpe, 1998). Age, education level and income are also positively related to higher financial literacy scores (Chen \& Volpe, 1998; Campbell, 2006). With the increasing cost of tuition and more students enrolling in college, debt and extreme financial conditions puts stress on the early life of young adults. Especially for those who are already at a disadvantage when it comes to financial literacy, having proper training is key in order to make sound financial decisions. Without the proper education on financial activities, a student's financial decisions could be negatively impacted for the rest of their lives. Studies suggest that financial classes in post-secondary education could provide a student with a better understanding of financial decisions for life post-graduation (Lusardi \& Wallace, 2013; Jappelli \& Padula, 2013). This study aims to explore options for financial literacy education, as well as the impact student confidence and motivation can have on this education.

\section{Hypotheses Development}

Previous research shows that many factors can play a role in a student's financial literacy, but does a student's major also play a role on the effect of financial planning? For example, would those who pursue a degree in business be more adept with the financial concepts in real world situation than those in other

fields of study such as Arts, Sciences and Nursing? Research has found that those who are familiar with a specific area are more likely to score higher on a test related to that (i.e. college students score higher on 
questions about car insurance than mortgage insurance) (Chen \& Volpe, 1998). Based on business programs requiring financial courses, business students should be more financially literate, as they are more familiar with financial topics than those who are not. The exception to this would be if other students (in art, science etc.) took financial courses that were outside the scope of their major. This exposure to financial courses would lead to higher financial literacy scores. Therefore:

\section{H1: Business students will be more financially literate than those who are not business students.}

H2: Students who have taken financial literacy courses will be more financially literate than those who have not.

An additional component to consider is the relationship between financial literacy and financial literacy among family members. Those who are closely tied to the world of finance should understand the concepts more than someone who is from a family that is disconnected with the field as they should be more familiar with the topic (Lusardi \& Wallace, 2013; Seyedian \& Yi, 2011). Therefore:

H3: Students who have family members in a financial field will score higher on the financial literacy test than those who do not.

While individual differences (race, income level, gender, education) have all been shown to impact an individual's financial literacy (Lusardi \& Wallace, 2013; Kramer, 2016; Firli, 2017), it is also important to see how these differences interact with a student's confidence. Financial literacy can be daunting for students, and even if they might be interested in learning more, they may be afraid, or not have the confidence that they can pursue more education or training in this area. Confidence levels and student performance have been shown to be related (Strage \& Brandt, 1999; Ramos-Sanchez \& Nichols, 2007). Specifically, researchers have found that those with higher confidence than their peers tended to perform better than those with lower confidence. Based on this, students that are more confident in their financial knowledge will be able to make better and more efficient decisions.

H4: Students who are more confident will score higher on the financial literacy test than those who are not.

Another key aspect of financial literacy is the overall participation by the individual. Financial literacy can be dependent on personal aspirations and motivation to learn the concepts (Seyedian \& Yi, 2011; Kramer, 2016; Jappelli \& Padula, 2013). Mandell and Klein (2007) found that motivational variables explained differences in financial literacy among participants. Therefore:

H5: Students who are more motivated will score higher on the financial literacy test than those who are not.

As studies suggest, discovering how to effectively educate students in financial literacy can greatly impact student future financial success (Mandell, 2006; Mandell \& Klein 2009). This research looks to replicate the relationships between student variables and financial literacy that other studies have found. It also seeks to understand how motivation and confidence impact this relationship in order to develop better financial literacy programming for all students. 
FIGURE 1

MODEL OF MOTIVATION AND CONFIDENCE ON FINANCIAL LITERACY SCORE

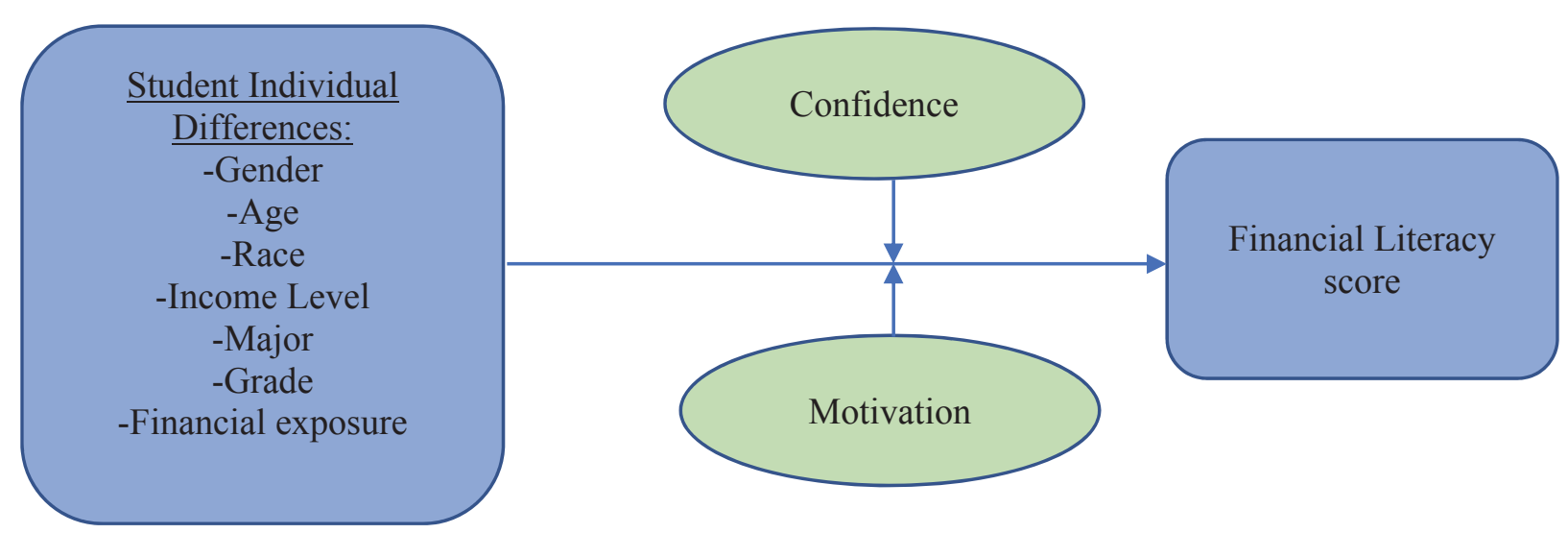

\section{METHODOLOGY}

A survey was sent to all of the undergraduate students at a large public university in the US through an email containing a link to Qualtrics. Participants who completed the survey were entered into a raffle for an Amazon gift card. Questions ranged from abilities, confidence and motivations in terms of financial literacy, to demographics. Participants also completed a financial literacy test. The financial literacy test used in this study was created by Van Rooij, Lusardi and Alessie (2011). It is an 11-question test that measures basic understanding of financial concepts (see appendix A). Questions include: "When an investor spreads his money among different assets, does the risk of him losing money increase, decrease etc. True or False: Buying a company stock usually provides a safer return than a stock mutual fund; If the interest rate falls, what should happen to bond prices?"

\section{RESULTS}

The survey received 446 responses, out of those responses 84 were removed for incomplete response or due to their lack of answering the financial literacy test portion. The current sample size is 362 participants. Table I shows the percentage of correct and incorrect reponses for the financial literacy test, as well as those who did not know the answer. Questions 5, 7, and 9 had the highest percentage of correct answers (above 60\%). These questions were about basic understanding of stocks. Questions 6 and 11 had the lowest percentage of correct answers with under $25 \%$ of students knowing the correct anwer. These questions were focused on rate of return and bonds. Half of participants (and nearly half at 44\%) selected I don't know for questions 2 and 4. These questions were about mutual funds, and demonstrates a lack of familiarity with them. 
TABLE 1

FINANCIAL LITERACY TEST RESULTS

\begin{tabular}{|l|r|r|r|r|r|}
\hline \multirow{2}{*}{ Correct } & Q1 & Q2 & Q3 & Q4 & \multicolumn{1}{c|}{ Q5 } \\
\cline { 2 - 6 } & $42.8 \%$ & $33.7 \%$ & $30.4 \%$ & $42.8 \%$ & $65.7 \%$ \\
\hline Incorrect & $33.4 \%$ & $16.0 \%$ & $36.2 \%$ & $13.0 \%$ & $8.6 \%$ \\
\hline Don't Know & $23.8 \%$ & $50.3 \%$ & $33.4 \%$ & $44.2 \%$ & $25.7 \%$ \\
\hline
\end{tabular}

\begin{tabular}{|l|r|r|r|r|r|r}
\hline & \multicolumn{1}{c|}{ Q6 } & \multicolumn{1}{c|}{ Q7 } & \multicolumn{1}{c|}{ Q8 } & Q9 & Q10 & \multicolumn{1}{c}{ Q11 } \\
\cline { 2 - 8 } Correct & $23.7 \%$ & $69.9 \%$ & $58.6 \%$ & $62.2 \%$ & $43.1 \%$ & $15.7 \%$ \\
\hline Incorrect & $51.4 \%$ & $9.1 \%$ & $17.1 \%$ & $12.7 \%$ & $20.7 \%$ & $41.2 \%$ \\
\hline Don't Know & $24.9 \%$ & $21.0 \%$ & $24.3 \%$ & $25.1 \%$ & $36.2 \%$ & $43.1 \%$ \\
\hline
\end{tabular}

Hypothesis 1 predicts that business students will be more financially literate than non-business students. To test this, an ANOVA was run and was significant $(\mathrm{F}(6)=10.991, \mathrm{p}<.000)$. When broken down by college, business students scored higher than any other college with a mean score of 6.5 .

TABLE 2

\section{MEAN SCORES BY COLLEGE}

\begin{tabular}{|l|r|r|}
\hline College & Mean Score & Std. Dev. \\
\hline Business & 6.5 & 2.65 \\
\hline Marine Sciences and Technology & 5.5 & 2.12 \\
\hline Engineering & 5.0 & 2.74 \\
\hline Not Specified & 4.6 & 2.98 \\
\hline Nursing & 3.8 & 2.58 \\
\hline Arts and Sciences & 3.8 & 2.54 \\
\hline Visual and Performing Arts & 3.5 & 2.71 \\
\hline
\end{tabular}

Hypothesis 2 predicts that students who have taken a financial literacy course would be more financially literate than students who have not taken a financial literacy course. This hypothesis was supported $(\mathrm{F}(1)=56.814, \mathrm{p}<.000)$. Those who have previously taken a financial literacy course $(\mathrm{M}=6.45$, $\mathrm{sd}=2.66)$ scored higher than those who have not $(\mathrm{M}=4.18, \mathrm{sd}=2.66)$.

Hypothesis 3 predicts that students who have family members in a financial field will score higher on the financial literacy test than those who do not. This hypothesis was supported $(\mathrm{F}(1)=3.939, \mathrm{p}=.048)$. Those who have family members who work in the financial industry $(\mathrm{M}=5.33, \mathrm{sd}=2.62)$ scored higher than those who did not $(\mathrm{M}=4.69$, $\mathrm{sd}=2.94)$.

Hypothesis 4 predicts that students who are more confident will score higher on the financial literacy test than those who are not. This hypothesis was supported $(\mathrm{F}(9)=3.811, \mathrm{p}<.000)$. Those who were more confident $(\mathrm{M}=5.95, \mathrm{sd}=3.09)$ scored higher on the test than those who were not as confident $(\mathrm{M}=3.00$, $\mathrm{sd}=3.46)$.

Hypothesis 5 predicts that students who are more motivated will score higher on the financial literacy test than those who are not. This hypothesis was not supported ( $\mathrm{p}>.625)$. Motivation did not seem to have any relationship to test scores. This may be due to the fact that there was little variation among the responses related to motivation. The majority of participants $(86 \%)$ said that they were motivated. 


\section{Additional Analysis}

There was a significant difference in test scores between males and females $(F(3)=10.803, p<.000)$. Males $(\mathrm{M}=5.9, \mathrm{sd}=2.83)$ scored higher than females $(\mathrm{M}=4.2, \mathrm{sd}=2.65)$. An ANCOVA using confidence as a covariant was also significant $(\mathrm{F}(4)=12.595, \mathrm{p}<.000)$ demonstrating a link between gender differences and confidence related to financial literacy. Using Process (Hayes \& Preacher, 2013), a mediation analysis was run on the data and was significant $(F(1)=20.355, p<.000)$. Confidence mediated the relationship between gender and financial literacy. Confidence also mediated the relationship between major and test scores $(\mathrm{F}(1)=22.6196, \mathrm{p}<.000)$, with visual and performing arts and arts and science students having lower confidence and lower scores. There were no significant difference in test scores based on race $(\mathrm{p}=.816)$ or age $(\mathrm{P}=.307)$. Household income $(\mathrm{F}(8)=1.944, \mathrm{p}=.05)$ appeared to have a threshold effect where those whose family made over $\$ 75,000$ scored higher than those who did not, however, this upward trend of scores reversed at $\$ 150,000$. Despite age not being significant, grade was, with students closer to graduation scoring higher $(\mathrm{F}(4)=2.538, \mathrm{p}=.04)$. After taking the financial literacy test, participants were again asked how they would rate their overall financial literacy. There was a significant difference here as well $(\mathrm{F}(4)=52.413, \mathrm{p}<.000)$. Students whose scores were lower rated themselves as being far below $(\mathrm{M}=2.22$, $\mathrm{sd}=1.99)$ or somewhat below average $(\mathrm{M}=4.46, \mathrm{sd}=2.29)$, while those who did well, rated themselves as somewhat $(\mathrm{M}=7.55, \mathrm{sd}=2.17)$ or far above average $(\mathrm{M}=5.29$, $\mathrm{sd}=3.09$ ).

\section{DISCUSSION}

These results demonstrate significant individual factors that can predict student financial literacy. Our first hypothesis shows that business students have a higher understanding of financial concepts than other majors. This is related to hypothesis 2 , where individuals who had a financial course before performed better. This finding highlights the fact that a general course in financial literacy could instill a large understanding for many students. Both of these results provide evidence that a university could pursue several avenues in order to increase the financial literacy amongst their students. Hypothesis 1 demonstrates that the basic business curriculum is fairly effective in increasing financial literacy. This curriculum can easily be made into a smaller and quicker format for all students to take along with their general courses towards their major of their choosing. This type of financial learning is again supported by hypothesis 2 where one financial class can have a positive impact on the financial literacy of a student. In order to make the process more efficient adding even one class that focuses on general financial topics could prove to be beneficial towards the university and its students.

Our study showed that higher confidence in their financial knowledge lead to a better score. This was especially true for gender, as men were more confident and scored higher than women. This points to a need for more support for women when learning this material. It also demonstrates a need to encourage women to take these types of classes as a way to feel more empowered and have more confidence in their abilities. This study shows that confidence plays a key role, impacting scores by gender and major and it should therefore be given further consideration.

While motivation did not play a significant role, students did say they have not taken a financial literacy course due to it not being part of their normal coursework. Adding a course that could be an elective for students who are currently not required to take one could be instrumental in increasing student financial literacy.

\section{LIMITATIONS AND CONCLUSIONS}

While these findings are valuable, this study did have several limitations. One limitation was our measurement of motivation. With a high percentage of individuals saying they were motivated, it seems that our scale was not able to clearly parse out accurate levels of student motivations through selfreporting. Also, while this study had a large sample size, it was only conducted on one college campus and should be replicated at other schools for generalizability. While these results are helpful, new 
strategies for teaching financial literacy should be tested in order to have a clearer idea of exactly what type of course would be most effective. While participants specified their preferred type of course to take, the effectiveness of this type of course has not been measured yet. Student willingness to take a financial literacy course should also be explored further. Studies show that there may be a large percentage of women or minorities who opt into a major that either avoids a large amount of math or finance courses, or that doesn't allow for a large variety of financial course due to the stress on core class knowledge.

Further exploration of the impact of confidence is extremely important as it can predict success in terms of financial literacy. Developing and maintaining confidence in this subject matter is essential and future research should look at ways to build confidence in financial literacy and learning.

To conclude, these results show that a lack of financial knowledge plays an important role in student financial literacy. To improve the financial literacy for college students as a whole, universities must inform students of the benefits of taking financial courses as well as create a curriculum early in the students' academic career that allows for their learning basic financial concepts.

\section{REFERENCES}

Bernheim, B. D., Garrett, D. M., \& Maki, D. M. (2001). Education and saving: The long-term effects of high school financial curriculum mandates. Journal of public Economics, 80(3), 435-465.

Cagan, P. (1965). The effect of pension plans on aggregate saving. National Bureau of Economic Research.

Campbell, J. Y. (2006). Household finance. The journal of finance, 61(4), 1553-1604.

Chen, H., \& Volpe, R. P. (1998). An analysis of personal financial literacy among college students. Financial services review, 7(2), 107-128.

Danes, S. M., \& Hira, T. K. (1987). Money management knowledge of college students. The Journal of Student Financial Aid, 17(1), 4-16. New York, NY

Dodaro, G. L. (2011). Financial literacy: The Federal government's role in empowering Americans to make sound financial choices. Washington, DC: US Government Accountability Office (GAO)

Employee Benefit Research Institute. (1995). Are workers kidding themselves? Results of the 1995 Retirement Confidence Survey. December, Washington, DC.

Firli, A. (2017). Factors that Influence Financial Literacy: A Conceptual Framework. In IOP Conference Series: Materials Science and Engineering, 180(1), 012254. IOP Publishing.

Funds/Girls Inc. (1997). Girls, money and independence. New York, NY.

Gustman, A. L., \& Steinmeier, T. L. (2001). How effective is redistribution under the social security benefit formula? Journal of Public Economics, 82(1), 1-28.

Hayes, A. F., \& Preacher, K. J. (2013). Conditional process modeling: Using structural equation modeling to examine contingent causal processes.

Hilgert, M. A., Hogarth, J. M., \& Beverly, S. G. (2003). Household financial management: The connection between knowledge and behavior. Fed. Res. Bull., 89, 309.

Jappelli, T., \& Padula, M. (2013). Investment in financial literacy and saving decisions. Journal of Banking \& Finance, 37(8), 2779-2792.

Katona, G. (1965). Private pensions and individual saving (No. 40). Survey Research Center, Institute for Social Research, University of Michigan.

KPMG Peat Marwick LLP (KPMG). (1995). Retirement benefits in the 1990s: 1995 survey data. June. New York, NY.

Kramer, M. M. (2016). Financial literacy, confidence and financial advice seeking. Journal of Economic Behavior \& Organization, 131, 198-217.

Lusardi, A., \& Mitchell, O. S. (2007). Baby boomer retirement security: The roles of planning, financial literacy, and housing wealth. Journal of monetary Economics, 54(1), 205-224.

Lusardi, A., \& Mitchell, O. S. (2008). Planning and financial literacy: How do women fare? American Economic Review, 98(2), 413-17. 
Lusardi, A., \& Wallace, D. (2013). Financial literacy and quantitative reasoning in the high school and college classroom. Numeracy, 6(2), 1.

Lusardi, A., \& Mitchelli, O. S. (2007). Financial literacy and retirement preparedness: Evidence and implications for financial education. Business economics, 42(1), 35-44.

Mandell, L. (2006). Financial literacy: Improving education results of the 2006 national Jump\$tart survey. Washington, DC: Jumpstart Coalition.

Mandell, L., \& Klein, L. (2009). The impact of financial literacy education on subsequent financial behavior.

Mandell, L., \& Klein, L. S. (2007). Motivation and Financial literacy. Financial Services Review, 16, 106-116.

Marcolin, S., \& Abraham, A. (2006). Financial literacy research: Current literature and future opportunities.

National Financial Educators Council (NFEC). (2017). Financial Literacy Statistics, Data, and Results. Retrieved from www.financialeducatorscouncil.org/financial-literacy-statistics/Oppenheimer

Princeton Survey Research Associates (PSRA). (1996). Investor knowledge survey. Investor Protection Trust, May. Arlington, VA.

Princeton Survey Research Associates (PSRA). (1997). Planning for the future: Are Americans prepared to meet their financial goals? Nations Bank Consumer Federation of America. Princeton, NJ.

Ramos-Sánchez, L., \& Nichols, L. (2007). Self-efficacy of first-generation and non-first-generation college students: The relationship with academic performance and college adjustment. Journal of College Counseling, 10(1), 6-18.

Seyedian, M., \& Yi, T. D. (2011). Improving Financial Literacy of College Students: A Cross-Sectional Analysis. College Student Journal, 45(1).

Strage, A., \& Brandt, T. S. (1999). Authoritative parenting and college students' academic adjustment and success. Journal of educational Psychology, 91(1), 146.

Vanguard Group/Money Magazine. (1997). Financial literacy of mutual fund investors. January, New York, NY.

Van Rooij, M., Lusardi, A., \& Alessie, R. (2011). Financial literacy and stock market participation. Journal of Financial Economics, 101(2), 449-472.

Volpe, R. P., Chen, H., \& Pavlicko J. J. (1996). Personal investment literacy among college students: A survey. Financial Practice and Education, 6(2), 86-94.

18 Journal of Higher Education Theory and Practice Vol. 19(4) 2019 